\title{
In Vitro Hepatoprotective Evaluation of Organolead(II) Complexes on Carbon Tetrachloride Induced Hepatotoxicity : Synthesis, Characterization and Biopotency
}

\author{
Ashu Chaudhary and R.V. Singh* \\ Department of Chemistry, University of Rajasthan, Jaipur - 302004 \\ E-mail : Singh-rv(a)unirai.ernet.in ; kudiwal@datainfosys.net
}

Fax : +91-141-2700451

\begin{abstract}
Administration of alcoholic solution of organolead(II) complexes protects the liver from the toxic effect of $\mathrm{CCl}_{4}$ by restoring the levels of serum, bilirubin, serum total protein, albumin and subsequent decrease in the levels of serum globulin in experimental rats. The serum alanine transaminase, aspartate transaminase and alkaline phosphatase activities were also restored as compared to the normal rats. Antibacterial activity of organolead(II) complexes derived from 1,4-diaminobutane and dicarboxylic acids are described with a structural support of micro estimations, IR, ${ }^{1} \mathrm{H}$ NMR, ${ }^{13} \mathrm{C}$ NMR and ${ }^{207} \mathrm{~Pb}$ NMR spectroscopy. The complexes have also been subjected for molecular weight determinations and conductivity measurements. The isolated products are coloured solids, soluble in dimethylsulfoxide, dimethylformamide and methanol. Conductivity measurements in dry DMF show them to be non-electrolytes. An octahedral geometry has been suggested for these complexes.
\end{abstract}

\section{INTRODUCTION}

Organolead compounds, a front area of inorganic and metal organic chemistry, have been receiving increasing attention due to the environmental /1-5/ as well as industrial and economic /6/ significances. Lead zirconium titanate (PZT) is a promising material in the field of computers. Various chelating agents have been evaluated in the therapy of lead poisoning $/ 7,8 /$ in both humans and animals.

Organolead compounds possess fungicidal as well as bactericidal activities $19,10 /$. It has also been suggested that these are suitable for the treatment of various allergies, asthma and influenza $/ 11 /$. Several organolead compounds find uses as good algicides, herbicides and also as anticancerous agents $/ 12-14 /$. The current interest is often inspired by some applications of organometallics in bioinorganic chemistry /15-17/.

An extension of our work, in order to develop biochemistry of synthetic organometallics, has generated 
active research relating to their biochemical significance. This communication deals with the synthesis, spectroscopic characterization and some new biodimensions in the structural and bioactivity patterns with the applied potential of some organolead(II) complexes.

\section{EXPERIMENTAL}

All the solvents used were of high purity and distilled before use. $\mathrm{PbCl}_{2}(\mathrm{BDH})$, malonic acid, succinic acid, glutaric acid and adipic acid (Fluka) and 1,4-diaminobutane (E. Merck) were used as obtained.

\section{Synthetic Procedure}

\section{Synthesis of the complex $\left[\mathrm{Pb}\left(\mathrm{Mac}^{1}\right) \mathrm{Cl}_{2}\right]$ (where Mac represents the macrocyclic structure shown in Fig. 1)}

The reaction was carried out in 1:2:2 molar ratios. A magnetically stirred solution of $\mathrm{PbCl}_{2}$ in methanol was added to a solution of 1,4-diaminobutane. The reaction mixture was stirred for 30 minutes and then the methanolic solution of malonic acid was added. The resultant mixture was stirred overnight to yield a solid product which was removed by filtration, washed several times with the same solvent and vacuum-dried. The compound was recrystallized in benzene. The purity of the products was checked by TLC on silica gel-G. However, when the same reaction was carried out under microwave conditions of "Green Chemistry", the products were formed within 5-8 minutes, which is also an advantage of the new technique from the environmental as well as from the economic point of view.

The same procedure has been used for the synthesis of $\left[\mathrm{Pb}\left(\mathrm{Mac}^{2}\right) \mathrm{Cl}_{2}\right],\left[\mathrm{Pb}\left(\mathrm{Mac}^{3}\right) \mathrm{Cl}_{2}\right]$ and $\left[\mathrm{Pb}\left(\mathrm{Mac}^{4}\right) \mathrm{Cl}_{2}\right]$. The reagents used were succinic acid, glutaric acid and adipic acid respectively, in place of malonic acid.

\section{Synthesis of the organolead(II) complexes}

The reaction was carried out in 1:1 molar ratio. In a Shlenk tube, a saturated methanolic solution of $\left[\mathrm{Pb}\left(\mathrm{Mac}^{i}\right) \mathrm{Cl}_{2}\right]$ was taken, stirred and pyridine was added. The stirred suspension was then cooled to $-5^{\circ} \mathrm{C}$ and stirred for 35 minutes. Sodium hydroxide $(0.006 \mathrm{~mol})$ followed by $\mathrm{CH}_{3} \mathrm{I}(0.003 \mathrm{~mol})$ were added. The solution was gradually warmed to $20^{\circ} \mathrm{C}$ and stirred further for 40 minutes. The solution was refluxed to half the volume, stirred, filtered and dried in vacuo. The physical properties of the complexes are given in Table 1.

The same procedure has been used for the synthesis of $\left[\mathrm{RPb}\left(\mathrm{Mac}^{\mathrm{n}}\right) \mathrm{C}_{5} \mathrm{H}_{5} \mathrm{~N}\right]$, where $\mathrm{n}=2-4, \mathrm{R}=\mathrm{CH}_{3}$ or $\mathrm{C}_{2} \mathrm{H}_{5}$. The reagents used were $\left[\mathrm{Pb}\left(\mathrm{Mac}^{2}\right) \mathrm{Cl}_{2}\right],\left[\mathrm{Pb}\left(\mathrm{Mac}^{3}\right) \mathrm{Cl}_{2}\right]$ and $\left[\mathrm{Pb}\left(\mathrm{Mac}^{4}\right) \mathrm{Cl}_{2}\right]$ with $\mathrm{CH}_{3} \mathrm{I} / \mathrm{C}_{2} \mathrm{H}_{5} \mathrm{Br}$.

\section{Physical measurements and analytical methods}

The molecular weights were determined by the Rast Camphor Method. Conductivity measurements in dry DMF were performed with a conductivity Bridge type 305. Nitrogen and chlorine were estimated by Kjeldahl's and Volhard's method, respectively. Lead was estimated as lead oxide gravimetrically. Infrared spectra of the precursors and their organolead(II) complexes were recorded in the range $4000-200 \mathrm{~cm}^{-1}$ with the help of a Nicolet-Magna FTIR-550 spectrophotometer as $\mathrm{KBr}$ pellets. ${ }^{1} \mathrm{H}$ NMR and ${ }^{13} \mathrm{C}$ NMR spectra 
were recorded in methanol, using TMS as the standard on a JEOL FX - 90Q spectrometer at $33.35 \mathrm{MHz}$. Carbon and hydrogen analyses were performed at Regional Sophisticated Instrumentation Center, Central Drug Research Institute, Lucknow.

Table 1

Physical Properties and Analytical Data of the Organolead(II) complexes.

\begin{tabular}{|c|c|c|c|c|c|c|c|}
\hline \multirow{2}{*}{ Compound } & \multirow{2}{*}{$\begin{array}{c}\text { M.P. }{ }^{\circ} \mathrm{C} \text { and } \\
\text { Colour }\end{array}$} & \multicolumn{5}{|c|}{ Analysis, Found (Calcd.) \% } & \multirow{2}{*}{$\begin{array}{c}\text { Mol. Wt } \\
\text { Found } \\
\text { (Calcd.) }\end{array}$} \\
\hline & & $\mathrm{C}$ & $\mathrm{H}$ & $\mathrm{N}$ & $\mathrm{CI}$ & $\mathrm{Pb}$ & \\
\hline$\left[\mathrm{Pb}\left(\mathrm{Mac}^{\prime}\right) \mathrm{Cl}_{2}\right]$ & $\begin{array}{c}178 \\
\text { White }\end{array}$ & $\begin{array}{c}28.38 \\
(28.48)\end{array}$ & $\begin{array}{c}3.89 \\
(4.09)\end{array}$ & $\begin{array}{c}8.64 \\
(9.49)\end{array}$ & $\begin{array}{c}11.49 \\
(12.01)\end{array}$ & $\begin{array}{c}34.63 \\
(35.09)\end{array}$ & $\begin{array}{c}567 \\
(590.46)\end{array}$ \\
\hline$\left[\mathrm{Pb}\left(\mathrm{Mac}^{2}\right) \mathrm{Cl}_{2}\right]$ & $\begin{array}{c}210 \\
\text { White }\end{array}$ & $\begin{array}{c}31.07 \\
(31.07) \\
\end{array}$ & $\begin{array}{c}4 / 44 \\
(4.56)\end{array}$ & $\begin{array}{c}8.21 \\
(9.06) \\
\end{array}$ & $\begin{array}{c}9.81 \\
(10.35) \\
\end{array}$ & $\begin{array}{r}33.02 \\
(33.50) \\
\end{array}$ & $\begin{array}{c}592 \\
(618.52) \\
\end{array}$ \\
\hline$\left[\mathrm{Pb}\left(\mathrm{Mac}^{3}\right) \mathrm{Cl}_{2}\right]$ & $\begin{array}{c}189 \\
\text { White }\end{array}$ & $\begin{array}{r}33.26 \\
(33.44) \\
\end{array}$ & $\begin{array}{c}4 / 89 \\
(4.99) \\
\end{array}$ & $\begin{array}{c}7.83 \\
(8.67) \\
\end{array}$ & $\begin{array}{c}10.51 \\
(10.97) \\
\end{array}$ & $\begin{array}{r}31.54 \\
(32.04) \\
\end{array}$ & $\begin{array}{c}617 \\
(646.57) \\
\end{array}$ \\
\hline$\left[\mathrm{Pb}\left(\mathrm{Mac}^{4}\right) \mathrm{Cl}_{2}\right]$ & $\begin{array}{c}205 \\
\text { White }\end{array}$ & $\begin{array}{c}35.50 \\
(35.61)\end{array}$ & $\begin{array}{c}5.18 \\
(5.38)\end{array}$ & $\begin{array}{c}7.35 \\
(8.30)\end{array}$ & $\begin{array}{r}10.03 \\
(10.51\end{array}$ & $\begin{array}{c}30.20 \\
(30.71)\end{array}$ & $\begin{array}{c}643 \\
(674.62)\end{array}$ \\
\hline$\left[\mathrm{CH}_{3} \mathrm{~Pb}\left(\mathrm{Mac}^{\mathrm{l}}\right) \mathrm{C}_{5} \mathrm{H}_{5} \mathrm{~N}\right]$ & $\begin{array}{c}170 \\
\text { Off white }\end{array}$ & $\begin{array}{r}39.04 \\
(39.14) \\
\end{array}$ & $\begin{array}{r}5.06 \\
(5.26) \\
\end{array}$ & $\begin{array}{c}10.60 \\
(11.41) \\
\end{array}$ & - & $\begin{array}{r}33.27 \\
(33.76) \\
\end{array}$ & $\begin{array}{c}587 \\
(613.69) \\
\end{array}$ \\
\hline$\left[\mathrm{CH}_{3} \mathrm{~Pb}\left(\mathrm{Mac}^{2}\right) \mathrm{C}_{5} \mathrm{H}_{5} \mathrm{~N}\right]$ & $\begin{array}{c}193 \\
\text { Off white }\end{array}$ & $\begin{array}{r}41.08 \\
(41.18) \\
\end{array}$ & $\begin{array}{r}5.44 \\
(5.65) \\
\end{array}$ & $\begin{array}{c}10.06 \\
(10.91) \\
\end{array}$ & - & $\begin{array}{c}31.75 \\
(32.28) \\
\end{array}$ & $\begin{array}{c}612 \\
(641.74) \\
\end{array}$ \\
\hline$\left[\mathrm{CH}_{3} \mathrm{~Pb}\left(\mathrm{Mac}^{3}\right) \mathrm{C}_{5} \mathrm{H}_{5} \mathrm{~N}\right]$ & $\begin{array}{c}185 \\
\text { Off white }\end{array}$ & $\begin{array}{r}43.04 \\
(43.04) \\
\end{array}$ & $\begin{array}{c}6.02 \\
(6.02)\end{array}$ & $\begin{array}{c}9.61 \\
(10.45) \\
\end{array}$ & - & $\begin{array}{r}30.45 \\
(30.93) \\
\end{array}$ & $\begin{array}{c}644 \\
(669.80)\end{array}$ \\
\hline$\left[\mathrm{CH}_{3} \mathrm{~Pb}\left(\mathrm{Mac}^{4}\right) \mathrm{C}_{5} \mathrm{H}_{5} \mathrm{~N}\right]$ & $\begin{array}{c}191 \\
\text { Off White }\end{array}$ & $\begin{array}{r}44.55 \\
(44.75) \\
\end{array}$ & $\begin{array}{r}6.28 \\
(6.35) \\
\end{array}$ & $\begin{array}{r}9.32 \\
(10.03) \\
\end{array}$ & - & $\begin{array}{r}29.19 \\
(29.69) \\
\end{array}$ & $\begin{array}{r}674 \\
(697.85) \\
\end{array}$ \\
\hline$\left[\mathrm{C}_{2} \mathrm{H}_{5} \mathrm{~Pb}\left(\mathrm{Mac}^{1}\right) \mathrm{C}_{5} \mathrm{H}_{5} \mathrm{~N}\right]$ & $\begin{array}{c}209 \\
\text { Cream }\end{array}$ & $\begin{array}{r}40.09 \\
(40.18) \\
\end{array}$ & $\begin{array}{c}5.36 \\
(5.46)\end{array}$ & $\begin{array}{c}10.21 \\
(11.16)\end{array}$ & - & $\begin{array}{c}32.50 \\
(33.01)\end{array}$ & $\begin{array}{c}594 \\
(627.71)\end{array}$ \\
\hline$\left[\mathrm{C}_{2} \mathrm{H}_{5} \mathrm{~Pb}\left(\mathrm{Mac}^{2}\right) \mathrm{C}_{5} \mathrm{H}_{5} \mathrm{~N}\right]$ & $\begin{array}{c}204 \\
\text { Cream } \\
\end{array}$ & $\begin{array}{r}42.02 \\
(42.12) \\
\end{array}$ & $\begin{array}{r}4.74 \\
(4.84) \\
\end{array}$ & $\begin{array}{c}9.74 \\
(10.68) \\
\end{array}$ & - & $\begin{array}{c}31.06 \\
(31.59) \\
\end{array}$ & $\begin{array}{r}623 \\
(655.77) \\
\end{array}$ \\
\hline$\left[\mathrm{C}_{2} \mathrm{H}_{5} \mathrm{~Pb}\left(\mathrm{Mac}^{3}\right) \mathrm{C}_{5} \mathrm{H}_{5} \mathrm{~N}\right]$ & $\begin{array}{c}198 \\
\text { Cream } \\
\end{array}$ & $\begin{array}{r}43.80 \\
(43.91 \\
\end{array}$ & $\begin{array}{r}6.08 \\
(6.19) \\
\end{array}$ & $\begin{array}{r}9.40 \\
(10.24) \\
\end{array}$ & - & $\begin{array}{r}29.83 \\
(30.29) \\
\end{array}$ & $\begin{array}{r}657 \\
(683.83 \\
\end{array}$ \\
\hline$\left[\mathrm{C}_{2} \mathrm{H}_{5} \mathrm{~Pb}\left(\mathrm{Mac}^{4}\right) \mathrm{C}_{5} \mathrm{H}_{5} \mathrm{~N}\right]$ & $\begin{array}{c}180 \\
\text { Cream } \\
\end{array}$ & $\begin{array}{r}45.35 \\
(45.55) \\
\end{array}$ & $\begin{array}{r}6.30 \\
(6.51) \\
\end{array}$ & $\begin{array}{c}8.89 \\
(9.84) \\
\end{array}$ & - & $\begin{array}{r}28.57 \\
(29.09) \\
\end{array}$ & $\begin{array}{c}680 \\
(711.89)\end{array}$ \\
\hline
\end{tabular}

\section{RESULTS AND DISCUSSION}

The products formed are solids and soluble in methanol, benzene, carbontetrachloride, dimethylsulphoxide and dimethyl formamide. The conductivity values measured for $10^{-3} \mathrm{M}$ solutions in 
anhydrous DMF are in the range $13-32 \mathrm{ohm}^{-1} \mathrm{~cm}^{2} \mathrm{~mol}^{-1}$, showing them to be non-electrolytes.

\section{IR Spectra}

The formation of the complexes has been revealed by the absence of $-\mathrm{NH}_{2}$ stretching vibrations of the amino acid and $\mathrm{OH}$ groups of the dicarboxylic acids. The amide groups are present at $1630-1680,1420-$ $1482,1235-1268$ and $582-674 \mathrm{~cm}^{-1}$ in the complexes $/ 18 /$. It provides a strong evidence for the presence of a closed cyclic product. Strong and sharp absorption bands appearing in the regions $2820-2865$ and 1400 - $1435 \mathrm{~cm}^{-1}$ in the complexes were assigned to the $\mathrm{C}-\mathrm{H}$ stretching and bending vibrational modes, respectively /19/. The presence of bands around $410-440 \mathrm{~cm}^{-1}$ assignable to $v(\mathrm{~Pb}-\mathrm{N})$ vibrations suggests that the amide nitrogen is coordinating to the lead ion $/ 20 /$. The IR spectral data of the complexes are listed in Table 2.

Table 2

IR Spectral Data $\left(\mathrm{cm}^{-1}\right)$ of the Lead(II) Complexes

\begin{tabular}{|c|c|c|c|c|c|c|}
\hline \multirow{2}{*}{ Compound } & \multicolumn{4}{|c|}{ Amide bands } & \multirow{2}{*}{$\mathrm{v}(\mathrm{NH})$} & \multirow{2}{*}{$v(\mathrm{~Pb}-\mathrm{N})$} \\
\hline & I & II & III & IV & & \\
\hline$\left[\mathrm{Pb}\left(\mathrm{Mac}^{1}\right) \mathrm{Cl}_{2}\right]$ & 1630 & 1424 & 1262 & 670 & 3190 & 438 \\
\hline$\left[\mathrm{Pb}\left(\mathrm{Mac}^{2}\right) \mathrm{Cl}_{2}\right]$ & 1640 & 1420 & 1240 & 673 & 3199 & 412 \\
\hline$\left[\mathrm{Pb}\left(\mathrm{Mac}^{3}\right) \mathrm{Cl}_{2}\right]$ & 1634 & 1460 & 1263 & 582 & 3172 & 410 \\
\hline$\left[\mathrm{Pb}\left(\mathrm{Mac}^{4}\right) \mathrm{Cl}_{2}\right]$ & 1666 & 1476 & 1235 & 658 & 3210 & 439 \\
\hline$\left[\mathrm{CH}_{3} \mathrm{~Pb}\left(\mathrm{Mac}^{\mathrm{l}}\right) \mathrm{C}_{5} \mathrm{H}_{5} \mathrm{~N}\right]$ & 1658 & 1480 & 1260 & 669 & 3266 & 424 \\
\hline$\left[\mathrm{CH}_{3} \mathrm{~Pb}\left(\mathrm{Mac}^{2}\right) \mathrm{C}_{5} \mathrm{H}_{5} \mathrm{~N}\right]$ & 1670 & 1472 & 1260 & 671 & 3274 & 438 \\
\hline$\left[\mathrm{CH}_{3} \mathrm{~Pb}\left(\mathrm{Mac}^{3}\right) \mathrm{C}_{5} \mathrm{H}_{5} \mathrm{~N}\right]$ & 1680 & 1482 & 1250 & 651 & 3238 & 420 \\
\hline$\left[\mathrm{CH}_{3} \mathrm{~Pb}\left(\mathrm{Mac}^{4}\right) \mathrm{C}_{5} \mathrm{H}_{5} \mathrm{~N}\right]$ & 1674 & 1481 & 1265 & 658 & 3247 & 427 \\
\hline$\left[\mathrm{C}_{2} \mathrm{H}_{5} \mathrm{~Pb}\left(\mathrm{Mac}^{1}\right) \mathrm{C}_{5} \mathrm{H}_{5} \mathrm{~N}\right]$ & 1678 & 1438 & 1248 & 674 & 3275 & 432 \\
\hline$\left[\mathrm{C}_{2} \mathrm{H}_{5} \mathrm{~Pb}\left(\mathrm{Mac}^{2}\right) \mathrm{C}_{5} \mathrm{H}_{5} \mathrm{~N}\right]$ & 1660 & 1465 & 1256 & 590 & 3256 & 440 \\
\hline$\left[\mathrm{C}_{2} \mathrm{H}_{5} \mathrm{~Pb}\left(\mathrm{Mac}^{3}\right) \mathrm{C}_{5} \mathrm{H}_{5} \mathrm{~N}\right]$ & 1662 & 1421 & 1268 & 610 & 3219 & 418 \\
\hline$\left[\mathrm{C}_{2} \mathrm{H}_{5} \mathrm{~Pb}\left(\mathrm{Mac}^{4}\right) \mathrm{C}_{5} \mathrm{H}_{5} \mathrm{~N}\right]$ & 1632 & 1436 & 1237 & 638 & 3278 & 424 \\
\hline
\end{tabular}

\section{'H NMR Spectra}

In order to substantiate the nature of bonding in the complexes discussed above, the proton magnetic resonance spectra of the complexes were recorded. The ${ }^{1} \mathrm{H}$ NMR spectra of the complexes do not show any 
signal corresponding to the amino and hydroxy groups. The broad signal observed in all the complexes at $\delta 7.98-8.15 \mathrm{ppm}$ is due to the amide (CO-NH) protons $/ 21 /$. In the spectra of the complexes, a multiplet observed in the region $\delta 1.97-2.09 \mathrm{ppm}$ may be ascribed to the middle methylene protons of the 1,4diamineobutane moiety.

In the spectra of the complexes a multiplet arising due to the methylene protons $\left(\mathrm{CO}-\mathrm{N}-\mathrm{CH}_{2}\right)$ appeared in the region $\delta 3.30-4.46 \mathrm{ppm}$. Similar data have been reported by several authors $/ 22,23 /$, showing the presence of $\mathrm{NH}$ group in the macrocyclic ring system. Singlets appearing in the regions $\delta 2.85-2.92$ and $3.05-3.10 \mathrm{ppm}$ are assigned to methylene protons of malonic and succinic acid moiety, respectively, while multiplets observed in the regions $\delta 3.20-3.23 \mathrm{ppm}$ and $\delta 3.27-3.29 \mathrm{ppm}$ are ascribed to the methylene proton of glutaric acid and adipic acid, respectively.

Table 3

${ }^{1} \mathrm{H}$ NMR $(\delta$, ppm) Spectral Data of the Lead(II) Complexes.

\begin{tabular}{|l|c|c|c|c|}
\hline Compound & $(\mathrm{CO}-\mathrm{NH})$ & $\left(\mathrm{CO}-\mathrm{N}-\mathrm{CH}_{2}\right)$ & $\mathrm{C}-\mathrm{CH}_{2}-\mathrm{C}$ & $\mathrm{CO}-\left(\mathrm{CH}_{2}\right)_{\mathbf{x}}-\mathrm{CO}$ \\
\hline$\left[\mathrm{Pb}\left(\mathrm{Mac}^{1}\right) \mathrm{Cl}_{2}\right]$ & 7.99 & 3.41 & 1.97 & 2.85 \\
\hline$\left[\mathrm{Pb}\left(\mathrm{Mac}^{2}\right) \mathrm{Cl}_{2}\right]$ & 8.08 & 3.32 & 2.03 & 3.05 \\
\hline$\left[\mathrm{Pb}\left(\mathrm{Mac}^{3}\right) \mathrm{Cl}_{2}\right]$ & 8.15 & 3.46 & 1.99 & 3.23 \\
\hline$\left[\mathrm{Pb}\left(\mathrm{Mac}^{4}\right) \mathrm{Cl}_{2}\right]$ & 8.06 & 3.44 & 2.03 & 3.27 \\
\hline$\left[\mathrm{CH}_{3} \mathrm{~Pb}\left(\mathrm{Mac}^{1}\right) \mathrm{C}_{5} \mathrm{H}_{5} \mathrm{~N}\right]$ & 8.05 & 3.36 & 2.05 & 2.92 \\
\hline$\left[\mathrm{CH}_{3} \mathrm{~Pb}\left(\mathrm{Mac}^{2}\right) \mathrm{C}_{5} \mathrm{H}_{5} \mathrm{~N}\right]$ & 8.10 & 3.40 & 2.10 & 3.09 \\
\hline$\left[\mathrm{CH}_{3} \mathrm{~Pb}\left(\mathrm{Mac}^{3}\right) \mathrm{C}_{5} \mathrm{H}_{5} \mathrm{~N}\right]$ & 8.12 & 3.37 & 1.98 & 3.22 \\
\hline$\left[\mathrm{CH}_{3} \mathrm{~Pb}\left(\mathrm{Mac}^{4}\right) \mathrm{C}_{5} \mathrm{H}_{5} \mathrm{~N}\right]$ & 7.98 & 3.41 & 2.09 & 3.28 \\
\hline$\left[\mathrm{C}_{2} \mathrm{H}_{5} \mathrm{~Pb}\left(\mathrm{Mac}^{1}\right) \mathrm{C}_{5} \mathrm{H}_{5} \mathrm{~N}\right]$ & 8.02 & 3.29 & 2.08 & 2.90 \\
\hline$\left[\mathrm{C}_{2} \mathrm{H}_{5} \mathrm{~Pb}\left(\mathrm{Mac}^{2}\right) \mathrm{C}_{5} \mathrm{H}_{5} \mathrm{~N}\right]$ & 8.12 & 3.32 & 2.09 & 3.10 \\
\hline$\left[\mathrm{C}_{2} \mathrm{H}_{5} \mathrm{~Pb}\left(\mathrm{Mac}^{3}\right) \mathrm{C}_{5} \mathrm{H}_{5} \mathrm{~N}\right]$ & 8.10 & 3.36 & 2.04 & 3.20 \\
\hline$\left[\mathrm{C}_{2} \mathrm{H}_{5} \mathrm{~Pb}\left(\mathrm{Mac}^{4}\right) \mathrm{C}_{5} \mathrm{H}_{5} \mathrm{~N}\right]$ & 7.99 & 3.30 & 1.97 & 3.27 \\
\hline
\end{tabular}

The conclusions drawn from the IR and ${ }^{1} \mathrm{H}$ NMR spectra are in agreement with the ${ }^{13} \mathrm{C}$ NMR spectral data regarding the authenticity of the proposed structure. The shift observed in the carbons attached with nitrogen atoms is indicative of their coordination with the central lead atom.

The X-ray powder diffraction study of the compound $\left[\mathrm{CH}_{3} \mathrm{~Pb}\left(\mathrm{Mac}^{4}\right) \mathrm{C}_{5} \mathrm{H}_{5} \mathrm{~N}\right]$ has been carried out in order to have an idea about the lattice dynamics of the compounds. The results show that the compound belongs to the "orthorhombic" crystal system having unit cell parameters $a=10.9400 \AA, b=22.8766 \AA, c=28.1274 \AA$ and $\alpha=\beta=\gamma=90^{\circ} \mathrm{C}$. 


\section{${ }^{207} \mathrm{~Pb}$ NMR Spectra}

The ${ }^{207} \mathrm{~Pb}$ NMR spectra have proved to be a powerful tool in assessing the coordination number of lead and in turn elucidating the structures of the derivatives. The ${ }^{207} \mathrm{~Pb}$ nuclear magnetic resonance spectra of the lead complexes exhibited a singlet at $-\delta 1953-1970$ ppm, indicating the hexacoordinated state $/ 24 /$.

On the basis of the above results the structure shown in Fig. 1 is proposed for the organolead(II) complexes.
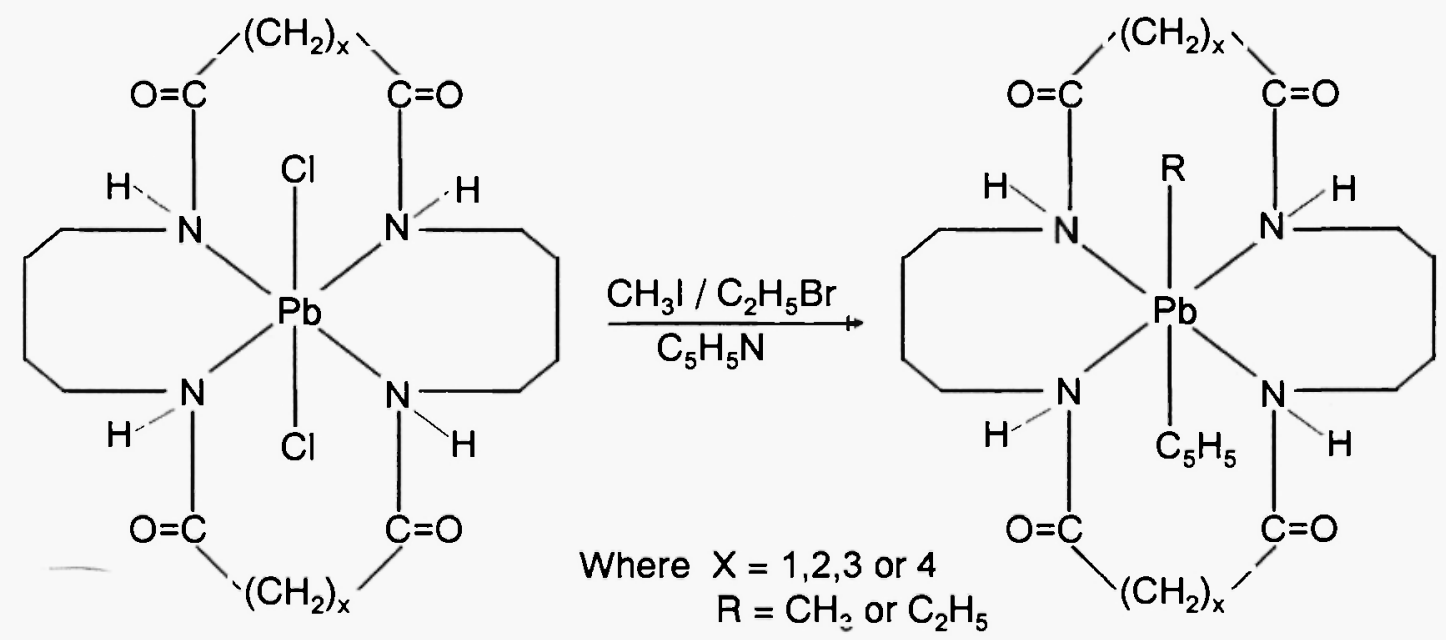

Fig. 1: Synthesis of the Complexes

\section{BIOPOTENCY}

\section{Antibacterial activity}

The antibacterial activity $/ 25 /$ of the test compounds was tested against $S$. aureus, P. aeruginosa, E. coli, Klebsiella and $C$. albicans using Mueller-Hinton agar medium. The antifungal activity of the test compounds was tested against $C$. albicans using sabourad dextrose agar medium. A sterile cotton swab was dipped into a suspension of microorganism (matched to McFarland barium sulphate standard) and the sterilized (autoclaved at $120^{\circ} \mathrm{C}$ for 30 minutes) medium was inoculated, and wells of diameter $(6 \mathrm{~mm})$ were punched in the agar plate with a sterile cork borer. The drug solution was added to these wells with a micropipette. After incubation at $37^{\circ} \mathrm{C}$ for $24 \mathrm{~h}$, the zone of inhibition was measured using mm scale. The observed zones of inhibition are presented in Table 4.

\section{Hepatoprotective Activity}

The experimental rats (male albino) weighing 180-200g) were divided into four groups of 10 each. The 
group I animals were treated as control. Hepatotoxicity was induced in the animals of group II, III and IV by oral administration of $\mathrm{CCl}_{4}(0.25 \mathrm{ml} / 100 \mathrm{~g}$ body weight $)$. Feeding was done biweekly for four weeks. From the fifth day onwards, the group II and group III animals received an oral dose $(50 \mathrm{mg} / 100 \mathrm{~g} \mathrm{~b}$ w for 30 days) of the compounds $\left[\mathrm{C}_{2} \mathrm{H}_{5} \mathrm{~Pb}\left(\mathrm{Mac}^{4}\right) \mathrm{C}_{5} \mathrm{H}_{5} \mathrm{~N}\right]$ and $\left[\mathrm{CH}_{3} \mathrm{~Pb}\left(\mathrm{Mac}^{4}\right) \mathrm{C}_{5} \mathrm{H}_{5} \mathrm{~N}\right]$ respectively. All the animals were fed on commercial standard pellet diet (Hindustan Lever Ltd., Mumbai), with water ad libitum and were maintained in the animal house (Zoology Department) at $25 \pm 2^{\circ}, 12 \mathrm{~h} \mathrm{light} /$ dark cycle and $60 \pm 5 \%$ relative humidity.

Table 4

Antimicrobial Activity of the Organolead Compounds

\begin{tabular}{|l|c|c|c|c|c|}
\hline Compound & S. aureus & P. aeruginosa & E. coli & Klebsiella & C. albicans \\
\hline$\left[\mathrm{CH}_{3} \mathrm{~Pb}\left(\mathrm{Mac}^{1}\right) \mathrm{C}_{5} \mathrm{H}_{5} \mathrm{~N}\right]$ & 6.5 & 10.1 & 8.2 & 6 & 5.1 \\
\hline$\left[\mathrm{CH}_{3} \mathrm{~Pb}\left(\mathrm{Mac}^{2}\right) \mathrm{C}_{5} \mathrm{H}_{5} \mathrm{~N}\right]$ & 6.8 & 11.3 & 8.0 & 6 & 5.9 \\
\hline$\left[\mathrm{CH}_{3} \mathrm{~Pb}\left(\mathrm{Mac}^{3}\right) \mathrm{C}_{5} \mathrm{H}_{5} \mathrm{~N}\right]$ & 8.1 & 12.6 & 9.4 & 7 & 6.7 \\
\hline$\left[\mathrm{CH}_{3} \mathrm{~Pb}\left(\mathrm{Mac}^{4}\right) \mathrm{C}_{5} \mathrm{H}_{5} \mathrm{~N}\right]$ & 9.0 & 13.7 & 9.9 & 7.8 & 7.3 \\
\hline$\left[\mathrm{C}_{2} \mathrm{H}_{5} \mathrm{~Pb}\left(\mathrm{Mac}^{1}\right) \mathrm{C}_{5} \mathrm{H}_{5} \mathrm{~N}\right]$ & 10.0 & 14.0 & - & 8.2 & 9.1 \\
\hline$\left[\mathrm{C}_{2} \mathrm{H}_{5} \mathrm{~Pb}\left(\mathrm{Mac}^{2}\right) \mathrm{C}_{5} \mathrm{H}_{5} \mathrm{~N}\right]$ & 10.2 & - & - & - & 8.1 \\
\hline$\left[\mathrm{C}_{2} \mathrm{H}_{5} \mathrm{~Pb}\left(\mathrm{Mac}^{3}\right) \mathrm{C}_{5} \mathrm{H}_{5} \mathrm{~N}\right]$ & 10.1 & - & 11.7 & 9.1 & 10 \\
\hline$\left[\mathrm{C}_{2} \mathrm{H}_{5} \mathrm{~Pb}\left(\mathrm{Mac}^{4}\right) \mathrm{C}_{5} \mathrm{H}_{5} \mathrm{~N}\right]$ & 11.2 & 14.9 & 13.4 & 10.2 & 11.3 \\
\hline $\mathrm{Standard}$ & 16.4 & 18 & 20 & 15 & 13 \\
\hline
\end{tabular}

Every week, three animals in each group were sacrificed and blood samples collected by direct heart puncture into a sterilized dried centrifuge tube. Clear serum was collected and used for the assay of total bilirubin $/ 26 /$, total protein and albumin/globulin ratio $/ 27 /$.

Injury and dysfunction of liver are caused by the toxic effect of $\mathrm{CCl}_{4}$ in experimental animals, and similar results are expected in the human viral hepatitis model $/ 28 /$. In $\mathrm{CCl}_{4}$-induced toxic hepatitis, a toxic reactive metabolite, trichloromethyl radical, was produced by the microsomaloxidase system. This activated radical bonds covalently to the macromolecules of the lipid membranes of endoplasmic reticulum and causes peroxidative degradation of lipids. As a result, fats from the adipose tissue were translocated and accumulated in the liver $/ 29 /$. In most of the studies this toxic chemical has been used as a tool to induce hepatotoxicity in experimental animals $/ 30 /$. 


\section{Assessment of hepatoprotective activity in carbon tetrachloride induced toxicity}

The biochemical parameters used are bilirubin, total protein, albumin, globulin, aspartate, aminotransminase, alanineamino transaminase and alkaline phosphatase. The major conclusions achieved by this experiment are as follows:

1. In the present study, at the end of each week of the treatment, blood samples of the $\mathrm{CCl}_{4}$ treated groups showed significant elevation in the serum levels, total bilirubin $(1.80-3.70 \mathrm{mg} / 100 \mathrm{ml})$, serum globulin $(2.50-2.80 \mathrm{mg} / 100 \mathrm{ml})$, aspartate aminotransaminase $(6.10-33.4 \mathrm{IU} / 100 \mathrm{mg}$ of protein), alanine aminotransaminase $(16.80-32.20$ Int. units/100 $\mathrm{mg}$ of protein) and alkaline phosphatase $(16.10-33.60$ IU/100 mg of protein) activities as compared to the controls. These elevations are indicative of cellular leakage and loss of functional integrity of the cell membrane $/ 31 /$. On the contrary, serum total protein and albumin levels decreased from $5.98-4.19$ and $3.50-1.35 \mathrm{mg} / 100 \mathrm{ml}$, respectively, as shown in Table 5.

Table 5

Hepatoprotective Activity of Organolead (II) Complexes.

\begin{tabular}{|c|c|c|c|c|c|c|}
\hline \multirow[t]{2}{*}{ Group of Animals } & \multicolumn{4}{|c|}{ Times in Weeks } & \multirow[t]{2}{*}{ F Value } & \multirow{2}{*}{$\begin{array}{l}\text { C. D at } \\
5 \%\end{array}$} \\
\hline & I & II & III & IV & & \\
\hline \multicolumn{7}{|c|}{ Total Bilirubin } \\
\hline Control & $0.85+0.10$ & $0.86 \pm 0.79$ & $0.73 \pm 0.06$ & $0.86 \pm 0.69$ & 2.74 & 0.018 \\
\hline$\left[\mathrm{C}_{2} \mathrm{H}_{5} \mathrm{~Pb}\left(\mathrm{Mac}^{4}\right) \mathrm{C}_{5} \mathrm{H}_{5} \mathrm{~N}\right]$ & $1.30 \pm 0.70$ & $1.46+0.34$ & $1.55 \pm 0.40$ & $1.59 \pm 0.15$ & 14.8 & 0.069 \\
\hline$\left[\mathrm{CH}_{3} \mathrm{~Pb}\left(\mathrm{Mac}^{4}\right) \mathrm{C}_{5} \mathrm{H}_{5} \mathrm{~N}\right]$ & $1.45 \pm 0.45$ & $1.50 \pm 0.05$ & $1.73 \pm 0.05$ & $1.79+0.06$ & 46.5 & 0.082 \\
\hline $\mathrm{CCl}_{4}$ & $1.80 \pm 0.05$ & $2.30 \pm 0.60$ & $2.75 \pm 0.15$ & $3.70 \pm 0.41$ & 55.2 & 0.315 \\
\hline \multicolumn{7}{|c|}{ Total Protein } \\
\hline Control & $7.24 \pm 0.23$ & $6.87+0.22$ & $6.90 \pm 0.25$ & $7.08 \pm$ & 0.451 & 0.442 \\
\hline$\left[\mathrm{C}_{2} \mathrm{H}_{5} \mathrm{~Pb}\left(\mathrm{Mac}^{4}\right) \mathrm{C}_{5} \mathrm{H}_{5} \mathrm{~N}\right]$ & $6.65 \pm 0.20$ & $6.42+0.15$ & $6.35 \pm 0.19$ & $6.25 \pm 0.15$ & 3.05 & 0.343 \\
\hline$\left[\mathrm{CH}_{3} \mathrm{~Pb}\left(\mathrm{Mac}^{4}\right) \mathrm{C}_{5} \mathrm{H}_{5} \mathrm{~N}\right]$ & $6.50+0.15$ & $6.37+0.24$ & $6.34 \pm 0.22$ & $6.12+0.19$ & 4.67 & 0.339 \\
\hline $\mathrm{CCl}_{4}$ & $5.98 \pm 0.24$ & $5.20 \pm 0.17$ & $4.82 \pm 0.29$ & $4.19 \pm 0.17$ & 39.6 & 0.350 \\
\hline \multicolumn{7}{|c|}{ Albumin } \\
\hline Control & $4.68 \pm 0.25$ & $4.50+0.20$ & $4.50 \pm 0.20$ & $4.78 \pm 0.30$ & 0.45 & 0.376 \\
\hline$\left[\mathrm{C}_{2} \mathrm{H}_{5} \mathrm{~Pb}\left(\mathrm{Mac}^{4}\right) \mathrm{C}_{5} \mathrm{H}_{5} \mathrm{~N}\right]$ & $4.20 \pm 0.35$ & $3.95 \pm 0.15$ & $3.72 \pm 0.20$ & $3.50 \pm 0.17$ & 4.46 & 0.362 \\
\hline$\left[\mathrm{CH}_{3} \mathrm{~Pb}\left(\mathrm{Mac}^{4}\right) \mathrm{C}_{5} \mathrm{H}_{5} \mathrm{~N}\right]$ & $3.70 \pm 0.20$ & $3.60 \pm 0.38$ & $3.50 \pm 0.17$ & $3.40 \pm 0.15$ & 1.59 & 0.414 \\
\hline $\mathrm{CCl}_{4}$ & $3.50 \pm 0.20$ & $2.50+0.25$ & $1.975+0.40$ & $1.35 \pm 0.12$ & 414.9 & 0.405 \\
\hline \multicolumn{7}{|c|}{ Globulin } \\
\hline Control & $2.40 \pm 0.81$ & $2.35+0.10$ & $2.340+0.73$ & $2.30 \pm 0.17$ & 0.18 & 0.207 \\
\hline$\left[\mathrm{C}_{2} \mathrm{H}_{5} \mathrm{~Pb}\left(\mathrm{Mac}^{4}\right) \mathrm{C}_{5} \mathrm{H}_{5} \mathrm{~N}\right]$ & $2.50 \pm 0.10$ & $2.50 \pm 0.20$ & $2.65+0.15$ & $2.55 \pm 0.10$ & 1.42 & 0.145 \\
\hline$\left[\mathrm{CH}_{3} \mathrm{~Pb}\left(\mathrm{Mac}^{4}\right) \mathrm{C}_{5} \mathrm{H}_{5} \mathrm{~N}\right]$ & $2.65 \pm 0.15$ & $2.74 \pm 0.17$ & $2.75 \pm 0.30$ & $2.78 \pm 0.10$ & 1.19 & 0.291 \\
\hline $\mathrm{CCl}_{4}$ & $2.58 \pm 0.10$ & $2.62+0.10$ & $2.80 \pm 0.16$ & $2.80+0.15$ & 5.80 & 0.183 \\
\hline
\end{tabular}




\begin{tabular}{|l|c|c|c|c|c|c|}
\hline \multicolumn{7}{|c|}{ Aspartate amino transaminase } \\
\hline Control & $0.45 \pm 0.10$ & $7.50 \pm 0.24$ & $7.78 \pm 0.50$ & $9.20 \pm 0.20$ & 12.9 & 0.598 \\
\hline$\left[\mathrm{C}_{2} \mathrm{H}_{5} \mathrm{~Pb}\left(\mathrm{Mac}^{4}\right) \mathrm{C}_{5} \mathrm{H}_{5} \mathrm{~N}\right]$ & $11.50 \pm 0.35$ & $14.20 \pm 0.30$ & $13.85 \pm 0.50$ & $15.05 \pm 0.30$ & 55.67 & 0.577 \\
\hline$\left[\mathrm{CH}_{3} \mathrm{~Pb}\left(\mathrm{Mac}^{4}\right) \mathrm{C}_{5} \mathrm{H}_{5} \mathrm{~N}\right]$ & $12.80 \pm 0.38$ & $14.10 \pm 0.21$ & $14.27 \pm 0.20$ & $16.35 \pm 0.60$ & 51.68 & 0.599 \\
\hline $\mathrm{CCl} 4$ & $16.80 \pm 0.40$ & $22.20 \pm 0.80$ & $25.76 \pm 0.70$ & $32.20 \pm 1.0$ & 245.7 & 1.160 \\
\hline \multicolumn{7}{|c|}{ Alamine amino transaminase } \\
\hline $\mathrm{Control}$ & $9.65 \pm 0.65$ & $9.85 \pm 0.51$ & $8.65 \pm 0.20$ & $8.40 \pm 0.65$ & 7.90 & 6.729 \\
\hline$\left[\mathrm{C}_{2} \mathrm{H}_{5} \mathrm{~Pb}\left(\mathrm{Mac}^{4}\right) \mathrm{C}_{5} \mathrm{H}_{5} \mathrm{~N}\right]$ & $14.30 \pm 0.25$ & $14.80 \pm 0.60$ & $14.80 \pm 0.77$ & $15.90 \pm 0.43$ & 8.90 & 0.890 \\
\hline$\left[\mathrm{CH}_{3} \mathrm{~Pb}\left(\mathrm{Mac}^{4}\right) \mathrm{C}_{5} \mathrm{H}_{5} \mathrm{~N}\right]$ & $12.70 \pm 0.60$ & $13.20 \pm 0.63$ & $14.02 \pm 0.50$ & $14.40 \pm 0.25$ & 5.16 & 0.985 \\
\hline $\mathrm{CCl}_{4}$ & $16.10 \pm 0.30$ & $20.90 \pm 0.24$ & $26.00 \pm 0.43$ & $33.40 \pm 1.50$ & 265.0 & 1.376 \\
\hline \multicolumn{7}{|c|}{ Alkaline phosphatase } \\
\hline $\mathrm{Control}^{7}$ & $9.67 \pm 0.50$ & $9.85 \pm 0.50$ & $8.65 \pm 0.20$ & $8.45 \pm 0.64$ & 7.75 & 0.728 \\
\hline$\left[\mathrm{C}_{2} \mathrm{H}_{5} \mathrm{~Pb}\left(\mathrm{Mac}^{4}\right) \mathrm{C}_{5} \mathrm{H}_{5} \mathrm{~N}\right]$ & $12.75 \pm 0.50$ & $14.80 \pm 0.50$ & $14.04 \pm 0.50$ & $14.47 \pm 0.28$ & 5.16 & 0.970 \\
\hline$\left[\mathrm{CH}_{3} \mathrm{~Pb}\left(\mathrm{Mac}^{4}\right) \mathrm{C}_{5} \mathrm{H}_{5} \mathrm{~N}\right]$ & $13.30 \pm 0.55$ & $14.76 \pm 0.40$ & $14.85 \pm 0.40$ & $15.60 \pm 0.40$ & 8.90 & 0.880 \\
\hline $\mathrm{CCl}_{4}$ & $16.10 \pm 0.34$ & $20.24 \pm 0.24$ & $25.00 \pm 0.44$ & $33.60 \pm 1.46$ & 263.5 & 1.278 \\
\hline
\end{tabular}

2. The estimation of serum total bilirubin confirms the intensity of jaundice. In a normal population, the serum bilirubin is in the range of 0.2 to $1 \mathrm{mg} / 100 \mathrm{ml}$ of serum. In viral or toxic hepatitis the degree of excretion of bilirubin from the intestine is much less and bilirubin present in the liver is excreted into the canaliculi and then regurgitated into the blood stream. Hence, hyperbilirubinemia is more common in hepatitis patients. At the end of each week of the treatment with $\left[\mathrm{C}_{2} \mathrm{H}_{5} \mathrm{~Pb}\left(\mathrm{Mac}^{4}\right) \mathrm{C}_{5} \mathrm{H}_{5} \mathrm{~N}\right]$ and $\left[\mathrm{CH}_{3} \mathrm{~Pb}\left(\mathrm{Mac}^{4}\right) \mathrm{C}_{5} \mathrm{H}_{5} \mathrm{~N}\right]$, significantly reduced levels of serum total bilirubin in the blood samples, even with the toxic effect of $\mathrm{CCl}_{4}$, were observed. The results are similar to those reported by earlier workers 133/.

3. That the liver synthesizes a number of serum proteins is well known. The change in the serum protein levels forms the basis for important laboratory aids to diagnose the depth of jaundice $34 /$. Further, there is a correlation between the degree of serum hypoalbuminemia and hyperglobulinemia. In a normal population the albumin/globulin ratio is in the range of 2:1. Table 4 depicts that, in $\mathrm{CCl}_{4}$-treated animals, serum total protein and albumin levels decreased with a moderate elevation in the levels of globulin. Even with the toxic effect of $\mathrm{CCl}_{4},\left[\mathrm{C}_{2} \mathrm{H}_{5} \mathrm{~Pb}\left(\mathrm{Mac}^{4}\right) \mathrm{C}_{5} \mathrm{H}_{5} \mathrm{~N}\right]$ and $\left[\mathrm{CH}_{3} \mathrm{~Pb}\left(\mathrm{Mac}^{4}\right) \mathrm{C}_{5} \mathrm{H}_{5} \mathrm{~N}\right]$ were effective in restoring the levels of decreased serum total protein from $6.65-6.10$ and $6.53-6.08 \mathrm{mg} / 100 \mathrm{ml}$, respectively, and levels of increased serum globulin from $2.45-2.55$ and $3.53-2.75 \mathrm{mg} / 100 \mathrm{ml}$, respectively. The percentage of serum protein level restored was found to be higher with $\left[\mathrm{C}_{2} \mathrm{H}_{5} \mathrm{~Pb}\left(\mathrm{Mac}^{4}\right) \mathrm{C}_{5} \mathrm{H}_{5} \mathrm{~N}\right]$.

4. The estimation of serum enzymes such as aspartate aminotransaminase (ALT), alanine aminotransaminase (AST) and alkaline phosphatase (ALP) individually are helpful in the differential diagnosis of hepatic disease /35/. The normal values of ALT, AST and SALP range from 5 to 20,5 to 15 and 7 to $9 \mathrm{IU} / \mathrm{mg}$ of protein, respectively. The concentration of these enzymes increases in serum whenever the liver tissue is damaged. It is presumably due to the release of enzymes from the damaged 
cells. In acute hepatic necrosis, the levels of AST and ALT are expected to increase 2 to 20 fold over that of controls. On the contrary, in obstructive and post-hepatic jaundice elevation of ALP was higher. In the present investigations, in the $\mathrm{CCl}_{4}$ treated group the activities of these enzymes increased parallelly from 1 to 4 weeks of treatments (Table 4). Administration of $\left[\mathrm{C}_{2} \mathrm{H}_{5} \mathrm{~Pb}\left(\mathrm{Mac}^{4}\right) \mathrm{C}_{5} \mathrm{H}_{5} \mathrm{~N}\right]$ and $\left[\mathrm{CH}_{3} \mathrm{~Pb}\left(\mathrm{Mac}^{4}\right) \mathrm{C}_{5} \mathrm{H}_{5} \mathrm{~N}\right]$ prevented an increase in the levels of these enzymes, showing the pattern of recovery from the toxic effect.

\section{ACKNOWLEDGEMENT}

The authors are indebted to CSIR New Delhi for financial assistance vide grants No. 9/149/(374)/2K2 EMR/I/2004 and 01(1956)/04/EMR-II and also thankful to Dr. Preeti Saxena for interpreting the hepatotoxicity activity data.

\section{REFERENCES}

1. S. Wingerters, H. Garnitzka, R. Betermann, S.K. Pandey, J. Rocha and D. Stalka, Organometallics, 19, 3890 (2000).

2. W.V. Zandt, J.C. Huffman and J.L. Stewart, Main Group Met. Chem., 21, 237 (1998).

3. H. Adams, R. Bastida, A. de Blas, M. Carnata, D.E. Fenton, A. Macias, A. Rodriguez and T. Rodriguez-Blas, Polyhedron, 16, 567 (1997).

4. O. Yu. Vassilyeva, V.N. Kokozay, N.A. Zhukova and L.A. Kovbasyuk, Polyhedron, 16, 1997, 263.

5. V. Alain, F. Pascal, B. Marie Laure, F. Russell and H. Bruno, Atmos. Environ., 33, 3377 (1999).

6. F. Chatput, J.P. Boilat, M. Lejeune, R. Papiernik and L.G.H. Pfalzgraf, J. Am. Ceram. Soc., 72, 1335 (1989).

7. Ahmad El-Wassef, Orient, J. Chem., 4, 102 (1988).

8. G. Hande, O. Hilal, O. Serdar and C. Nuran, Free Radical Biol. Med., 27, 75 (1999).

9. P. Dixit and J.P. Tandon, Phosphorus, Sulfur and Silicon, 53, 389 (1990).

10. A. Kumari, R.V. Singh and J.P. Tandon, Phosphorus, Sulfur and Silicon, 56, 195 (1993).

11. I. Prokopenko, N.N. Liatvinov, D.M. Klimova, R.A. Dmitriena, V.P. Ilin, T.L. Mazurina, O.P. Pugacheva, K.K. Kuznetzova and T.A.K. Kina, Gig. Sanit., 2, 9 (1989).

12. G. Ferhandez Leborans and M.A. Antonia Garcia, Acta Protozocol., 27, 141 (1988).

13. J.L. Stauber and T.M. Florence, Water Res., 23, 907 (1989).

14. M.R. Moors and P.A. Meredith, Arch. Toxicol., 42, 87 (1979).

15. M. Mitewa and P.R. Bontcher., Coord. Chem. Rev., 135/136, 129 (1994).

16. I. Ito, M. Kato, M. Yamashito and H. Ito, J. Coord. Chem., 15, 29 (1986).

17. M.P. Mertes and K.B. Mertes, ACC Chem. Res., 23, 413 (1990).

18. W.K. Pandey, O.P. Pandey, S.K. Sengupta and S.C. Tripathi, Polyhedron, 6, 1611 (1987). 
19. M.B.H. Hawlader, M.S. Islam and M.R. Karim, Indian J. Chem., 39A, 107 (2000).

20. A. Bansal and R.V. Singh, Bol. Soc. Chil. Quim., 45, 479-486 (2000).

21. M. Shakir and S.P. Varkey, Polyhedron, 14, 1117 (1995).

22. T.C. Woon and D.P. Fairlie, Inorg. Chem., 31, 4069 (1992).

23. I. Tabushi, Y. Taniguchi and H. Kato, Tetrahedron Lett., 12, 1049 (1977).

24. A. Chaudhary, A. Phor and R.V. Singh, Main Group Met. Chem., 1, 27 (2004).

25. S.H. Gillespie, in: Medical Microbiology Illustrated, Butterworth Heinemann, London, 1994, 234.

26. H.T. Mallory and E.A. Evelyn, J. Biol. Chem., 119, 481 (1937).

27. S.R. Kingsley, J. Biol. Chem., 122, 131 (1939).

28. Y. Aoto, Acta Hepatol., 25, 204 (1984).

29. H. Okuno, H. Hazama, T.S. Muraze and Y.T. Someshima, Jpn. J. Pharmacol., 41, 363 (1986).

30. S. Patil, A. Kanose and A.T. Varute, Indian J. Exp. Biol., 31, 265 (1993).

31. B. Saraswath, P.K.S. Visen, G.K. Patnaik and B.N. Dhawan, Indian J. Exp. Biol. 31, 316 (1993).

32. J.B. Henry, in: Saunders, W.B., Ed. Clinical Diagnosis and Management by Laboratory Methods, 7th Edn., Philadelphia, 1986, 241.

33. S.R.M. Murthy and M. Srinivasan, Indian J. Pharmacol., 25, 34 (1993).

34. P.K.S. Visen, B. Saraswat, G.K. Patnaik, R.C. Srimal, R.P. Tripathi and D.S. Bhakuni, Indian J. Pharmacol., 25, 149 (1993).

35. R.B. Drotman and G.T. Lawhorn, Drug Chem. Toxicol., 1, 163 (1978). 
